\title{
GOD AND EVIDENCE: A COOPERATIVE APPROACH
}

\author{
PAUL K. MOSER \\ Loyola University Chicago
}

\begin{abstract}
This article identifies intellectualism as the view that if we simply think hard enough about our evidence, we get an adequate answer to the question of whether God exists. The article argues against intellectualism, and offers a better alternative involving a kind of volitional evidentialism. If God is redemptive in virtue of seeking divine-human reconciliation, we should expect the evidence for God to be likewise redemptive. In that case, according to the article, the evidence for God would aim to draw the human will toward cooperation with God's will. Accordingly, the available evidence for God would be volitionally sensitive in that one's coming to possess it would depend on one's volitional stance toward its source. The article identifies some implications for divine hiddenness, traditional natural theology, and the view that the evidence for God's existence is akin to evidence for a scientific hypothesis.
\end{abstract}

In the noisy courtroom of public opinion, a theology stands or falls with its accompanying epistemology, in particular, with its stand on the matter of the evidence for God. If God is truly redemptive in seeking divine-human reconciliation, as suggested by large strands in the Jewish and Christian traditions, we should expect the evidence for God to be correspondingly redemptive. The implications of this lesson for theology are significant but widely neglected. This paper draws out some of these implications, and explains why a theology of a truly redemptive God resists any quick and easy dismissal on epistemological grounds and instead offers a profound existential challenge for inquirers about God.

\section{INTELLECTUALISM AND ITS UNDERPINNINGS}

If we simply 'think hard enough' about our evidence, do we get an adequate answer to the question of whether God exists? If we answer yes, then we favour an intellectualist approach to the question of whether God 
exists. Such an intellectualist approach includes among its supporters atheists as well as theists. If one holds that the adequate answer received by thinking hard enough is no, then one is an atheist (for purposes of our discussion). In contrast, if one holds that the adequate answer is yes, then one is a theist.

We may call a proponent of an intellectualist approach, whether atheist or theist, an intellectual about the question of God's existence. An intellectual, in this sense, can come from any academic discipline or from no such discipline. The discipline of academic philosophy, however, houses a large representation of intellectuals regarding God's existence, owing perhaps to its including some influential figures in the history of the intellectualist position. We may call their common position intellectualism, for lack of a better term. Bertrand Russell, for instance, was an influential proponent of intellectualism; he imagined himself protesting as follows upon meeting God: 'God, you gave us insufficient evidence.' (1970; cf. Dawkins 2006: 74-77) This paper contends that intellectualism is suspect at best and arguably false. In doing so, it will identify some widely neglected limits of human thinking relative to the evidence underlying human faith in God.

A person's 'thinking hard enough', according to intellectualism, is not just a matter of having a lot of thoughts, as if the sheer quantity of one's thoughts was the key. The hard thinking in question includes one's using arguments, that is, one's using premises to infer conclusions, either deductively or inductively. This raises the question of the value of arguments regarding God's existence. Is our thinking hard about such arguments sufficient for our having an adequate answer to the question of whether God exists? The answer is no if humans can, and sometimes do, have relevant evidence independent of arguments regarding God's existence. For example, if a human can have a direct experience of God, which is neither a thought nor an argument, then there will be room for relevant evidence independent of arguments regarding God's existence. We should not exclude such experiential evidence at the start, in order to avoid begging some important questions about the evidence for God's existence. (See Moser 2008, chap. 2, and 2010, chap. 4, for an attempt to make room for such evidence; cf. Farmer 1943, chaps. 3-4.)

When is an answer to the question of whether God exists 'adequate'? An intellectual will offer this reply: when an answer comes from our 'thinking hard enough' about our evidence, it is adequate. Even so, a convincing reply needs to offer more, given that adequacy in an answer 
to our question comes from various domains. Objective adequacy requires the correctness or the truth of an answer, whereas evidential adequacy requires the suitable fit of an answer with one's overall evidence, but does not require the answer's truth. A person's overall evidence can be incomplete in a way that falls short of yielding truth in beliefs based on that evidence. For instance, widely shared astronomical evidence before Copernicus and Galileo was incomplete in this manner, at least in certain areas of inquiry.

Cognitive adequacy, let us assume, includes both objective adequacy and evidential adequacy. Genuine knowledge that a claim is true has this kind of adequacy, regardless of whether one knows that one has this knowledge. Many philosophers seek cognitive adequacy in their answers, because they seek to know that their answers are true. For current purposes, we may sidestep the many complications arising from Gettier-style problems for the view that justified true belief is sufficient for knowledge that a proposition is true (for some relevant details, see Moser 1989, Shope 2002).

If intellectuals seek cognitive adequacy in their answer, they seek not only evidential adequacy but also objective adequacy. We have suggested, however, that the connection between evidential adequacy and objective adequacy is contingent, because the suitable fit of a contingent answer with one's overall evidence does not entail that the answer is true. This raises the issue of whether our thinking hard enough about our evidence will automatically yield an adequate answer to the question of whether God exists, if cognitive adequacy is the goal. The gap between evidential adequacy and objective adequacy in various actual cases recommends a negative reply to this issue.

It would be implausible to retreat to the view that we (should) care only about evidential adequacy, and not objective adequacy. Many people do care about objective adequacy, because they seek a correct answer to the question of whether God exists. In addition, evidential adequacy as characterized above is too limited for the purposes of many people. These people seek an answer that fits not only with the evidence we have but also with the evidence available to us. The evidence we now have can be arbitrarily or prejudicially restricted by us, such as when we arbitrarily or prejudicially exclude the pursuit of further relevant evidence in a case. Our available evidence, in contrast, transcends such arbitrary or prejudicial exclusion. 
Consider a case involving my trusted employee who has always exhibited honesty and reliability at his job in the past. An equally trusted supervisor, however, has just called my attention to what appear to be this employee's financial irregularities in some recent transactions at work. I now have a difficult choice to make, regarding whether to investigate my trusted employee by pursuing and gathering further available evidence regarding his reliability. My current evidence does not indicate that this employee is unreliable; on the contrary, my preponderant evidence, based on an extensive work history, indicates that he is reliable. As for available evidence I do not (yet) possess, it may undermine the previous evidence by indicating that the employee is actually unreliable. If I seek a resilient answer to the question of whether my employee is reliable, I will need to pursue further available evidence that I do not yet possess. Perhaps most employers would undertake this kind of pursuit, but I could refuse to do so, owing, for instance, to fear of destroying my longstanding friendship with this employee.

We may have difficulty in specifying exactly when evidence is available in some cases, but this general point does not count against a distinction between the broader evidence available to us and the more limited evidence we now have (or, possess). For current purposes, let's suppose that we now 'have' evidence only if we have had a salient awareness of it, but that we need not have had such an awareness of evidence available to us. This distinction will enable us to proceed with some clarity. (For an attempt to recruit this distinction to challenge evidence-based atheism, see Moser 2012a. The current paper identifies the broader significance of this distinction for an epistemology involving a redemptive God.)

\section{INTELLECTUALIST SHORTCOMINGS}

Evidence could be available to me but be sensitive, in its being possessed by me, to a certain volitional stance or inclination of mine, even if I do not actually possess the evidence in question. The volitional stance could include my being willing to love or to be faithful in a certain manner, perhaps toward the source of the available evidence. In this scenario, I could fail to possess the relevant available evidence as a result of my failing to love or to be faithful in a certain manner. I thus could be responsible, owing to my adopted volitional stance, for my not possessing evidence that is available to me. (Here we may use a conception of love, such as that of agape in the New Testament, which requires one's intentionally 
caring for what is good for people. For some helpful background for this conception, see Furnish 1972; cf. Ferré 1961.)

Suppose that you refuse to confide in me regarding your deepest motives in life, because (you know that) I do not have the proper love for you and hence should not be trusted with evidence regarding your deepest motives. We might imagine that I am the town gossip who cares only about the attention I bring to myself, even at the expense of others. Accordingly, you hide yourself from me in terms of who you really are, since I am a real threat to your good purposes, if not to your dignity as a person. In fact, it may be harmful to me as well as you to reveal your deepest motives to me, because I would handle this information in a bad way for all involved.

Understandably, you would have no desire to enable, or otherwise to promote, my harmful tendencies in handling confidential information. As a result, you plausibly would withhold from me evidence regarding your deepest motives and hence regarding yourself, that is, evidence concerning who you really are. Even so, that evidence would be available to me, because (we may suppose) you would give it to me upon my coming to love you or to be faithful to you. We may call this volitionally sensitive available evidence, because my coming to possess this evidence would depend on my volitional stance toward the source of the evidence.

God could have good, redemptive purposes in making at least some available evidence of God volitionally sensitive in its being possessed by us humans. This evidence then would be sensitive to our volitional stance toward God and God's will. God could be evidentially elusive in this manner for purposes of redeeming humans via moral-character transformation toward God's character of perfect love (agapē). That is, God could hide or withhold evidence of God's reality for the good of potential recipients of this evidence. This divine hiding could save (at least some) people from rejecting God outright when they are not ready to receive God as the rightful LoRD of their lives. In that case, they would not be prepared to handle the evidence redemptively, in keeping with God's good purposes toward divine-human reconciliation.

As redemptive, God would care about how people respond to evidence of God's reality, and would offer such evidence accordingly. As a result, God would not be a promiscuous exhibitionist or a superficial entertainer regarding the divine evidence offered to humans. More specifically, God would preserve a redemptive role for available divine evidence by encouraging its pursuit with a cooperative, obedient human 
will. Such a human pursuit of divine evidence would contrast with any passive reception of evidence by humans. A number of Biblical writers emphasize the importance of human pursuit of God. For instance, Jeremiah assigns the following announcement to God: 'When you search for me, you will find me; if you seek me with all your heart, I will let you find me, says the LoRD.' (Jer. 29:13-14, NRSV; cf. Lk. 11:9-13, Matt. 7:7-11) Human pursuit of God and evidence for God can bring needed focus to human wills and lives, and prevent humans from becoming complacent and presumptuous relative to God. Such a pursuit, therefore, can contribute to the redemption of humans as reconciliation to God.

God could bob and weave in divine self-manifestation, for the sake of challenging people to approach God with due seriousness and reverence, and not to treat God as a controllable or dispensable object. In particular, some people may wake up to God as a valuable reality after feeling God's absence in their lives but then being confronted by God's self-manifestation, perhaps by the presentation of divine agape in their conscience. We humans sometimes learn deeply from a sharp contrast between the absence and the presence of something in our experience. A redemptive God would seek to elicit a human decision in favour of God's character of agape, in particular, a priority commitment that puts God and God's moral character first in human life. In this respect, redemption would be cooperative, as humans resolve to share in God's moral character as a priority in their lives. (On the central role of human decision in redemption, see Minear 1966, chap. 3; Moser 2013, chap. 4.)

The relevant idea of divine self-manifestation in agape figures in the apostle Paul's understanding of the evidential basis for belief and hope in God (see, for instance, Rom. 5:5, 10:20). Following Isaiah, Paul invokes God's self-manifestation to unexpecting humans (in particular, Gentiles), and he understands it as seeking to 'pour out' divine agapē within receptive humans. This self-manifestation, being redemptive, would seek to have humans put divine agape first in their lives, above all the alternatives, in keeping with the greatest love-command (see Ramsey 1943). Paul seems to hold that God's self-disclosure is sensitive, at least to some extent, to human disclosure to God, whereby one allows oneself to be known, and laid hold of, by God (see Gal. 4:9; cf. Phil. 3:12). In any case, we should allow that God can disclose God's will to a person, perhaps in conscience, without that person's knowing that it is God's will thereby disclosed. (On the role of conscience, see Forsyth 1909, chap. 7.) 
We should not infer that a person must earn or merit (evidence of) God's self-manifestation or become morally perfect to be presented with it. Such an inference would seriously distort the moral character of a God who is worthy of worship and hence gracious and merciful. Instead, we should consider that a person may need to be willing to cooperate with God's perfect will if that person is to receive a clear self-manifestation from God. The problem is not that God would be personally injured in a devastating way by uncooperative humans; it is rather that such humans can dishonour (the dignity of) God and themselves. In fostering such dishonour, one can bring about a kind of relational harm, that is, harm to a potential good relationship between humans and God. One thereby could harm the purpose of God's self-manifestation to humans, if only by frustrating it, and thus harm oneself in turn.

Suppose that God seeks to redeem all constitutive aspects of human persons, including not just human thinking but also the willing, or volitional, activity integral to human agency. God then would offer a challenge to these aspects of human persons for the sake of their being transformed toward God's character and purposes and thus reconciled to God. This involves the question of who God wants a redeemed person to be in relation to God. It is plausible to suppose that God would desire redeemed human agents who reflect God's moral character and agency in intention and action, and not just redeemed thinkers. The volitional activity central to human agency is not just thinking or even thinking hard about evidence. It involves decisions regarding the kind of person one aims to be, in terms of moral character and practice. As a result, moral responsibility looms large in the make-up of a mature human agent. In being redemptive, God would not neglect the volitional make-up of human agents, but rather would aim to lead it, non-coercively, into cooperation with God's perfect will.

In the spirit of Job, humans often strive to understand God and God's providential ways to gain security and assurance for themselves. We should not expect God's security or assurance, however, to arise from mere human understanding, which is painfully limited in scope, especially regarding God's purposes in particular cases. Instead, we should expect divine security and assurance for humans to emerge from their volitional activity in response to God. This lesson fits with the following simple but profound remark from the prophet Micah: 'What is good, and what does the LORD require of you but to do justice, and to love kindness, and to walk humbly with your God.' (Micah 6:8, NRSV) 
In Micah's perspective, God aims for more than hard thinking by humans, even hard thinking with correct and well-grounded content. God aims, in addition, for volitional activity from humans that includes loving and obeying God. Clearly, such volitional activity is not captured by 'thinking hard' about evidence. I can think hard about, and even accept, evidence for God but not welcome, love, or obey God at all. The volitional activity in question can be an avenue to more, and even better, evidence regarding God, as a human conforms to God's redemptive expectations. So, the evidence for God's reality from divine selfmanifestation could be sensitive to human wills, and thus could allow for divine hiding in the face of volitional resistance. In this portrait of God, we cannot simply think ourselves into an objectively adequate answer regarding God's reality, because God would want, by way of redemption, more than our thinking. God would want to redeem our full agency, including our volitional features (such as our love), because God would want us to reflect divine moral agency in willing cooperation with God. If God would not want the latter, then God would not want what is best for us, and this would rob God of worthiness of worship.

One's being willing to obey God, in keeping with God's perfect will, mirrors the crisis of Jesus in Gethsemane. Seeking to obey God and thereby to inaugurate God's kingdom, Jesus found himself called by God to give up his own life in self-sacrifice to God for the sake of others. This was a temporary struggle between Jesus and God, where Jesus anticipated his arrest and crucifixion by Roman officials as part of God's plan of redemption. Mark's Gospel sketches the situation: '[Jesus and his disciples] went to a place called Gethsemane ... He said to them, "I am deeply grieved, even to death ..." [H]e threw himself on the ground and prayed that, if it were possible, the hour [of his arrest and crucifixion] might pass from him. He said, "Abba, Father, for you all things are possible; remove this cup [of suffering and death] from me; yet, not what I want, but what you want"' (Mark 14:32-36, NRSV)

Gethsemane begins with a humanly experienced conflict between a human want and a divine want, but ends with a resolution in a human plea to God in favour of God's will. Accordingly, the Gethsemane approach to God puts God's perfect will first, even when a serious human want must yield to God's volitional challenge. The challenge from God could come in human conscience, where one is convicted by God of wandering away from what is good or right, and this challenge could be encouraged by other humans. Even if some people regard human 
conscience as just socially informed by humans, God still could work in conscience to challenge people to cooperate with God's will. In that case, receptive humans could find the God who hides, not in mere reflection, but instead in the experiential and volitional conflict of a Gethsemanestyle crisis, where God offers a new mode of life to humans on God's perfect terms. In following the example of Jesus in Gethsemane, humans then would resolutely allow God to be God at least in some area of their volitional and practical lives.

We might think of a Gethsemane crisis as providing an opportunity for a kind of practical rationality toward God, via one's willingly moving toward cooperation with God. That is, one's will could move toward God's will by one's responding in obedience to God's challenging selfmanifestation in human conscience. If this is practical rationality toward God, its practicality consists in the non-coerced exercise of one's will to comply with God's will. It also would be substantive practical rationality, because it would encompass genuine goodness in cooperation with God's perfect will. In other words, it would not be purely instrumental practical rationality. God would represent a standard of goodness independent of the variability of human preferences or ends. In addition, God could nudge and encourage receptive people toward a Gethsemane crisis, and, therefore, they would not have to set up this crisis on their own. God would bring Gethsemane to humans as needed, at the opportune times.

In the perspective offered here, intellectualism is an inadequate approach to the question of whether God exists. It neglects the plausible view that God would have definite redemptive purposes for humans and would reveal the evidence for God accordingly. As a result, God could provide available evidence for God's reality that is volitionally sensitive, in its being possessed by a human, to the direction of one's will relative to cooperation with God's will. Many philosophers overlook this view, because they assume, in the tradition of Plato and Aristotle, that God is (or would be) immutable or static rather than purposively elusive. It seems, however, that a God who is worthy of worship and hence morally perfect would have to be purposively elusive for the good of potential human recipients of divine evidence. Such a God would oppose half-heartedness in humans toward God, and seek instead their whole-hearted commitment to God (see, e.g., Deut. 4:29, Jer. 29:13, Mk. 12:29-30; on the idea of God as elusive, see Minear 1966, chap. 8, Terrien 1978, Moser 2008). 
We should acknowledge some pre-receptive evidence for God, where a person has initial evidence for God's self-manifestation (perhaps in conscience) but does not cooperate with God at all. Such evidence would be elusive, unstable, and thin, because God would not want people to rest content with it, apart from cooperating with God. Consider a resolute enemy of God such as the Biblical character called 'Satan', who believes that God exists but does not receive God cooperatively as the LORD of his life. Satan can reasonably believe (on elusive, pre-receptive evidence) that God exists, because God has self-manifested divine reality to Satan to a very limited extent. However, in rejecting God's will, Satan has freely prevented God from manifesting divine reality to a redemptive, cooperative extent, where God's powerful love is poured out in his heart (cf. Rom. 5:5). In the Biblical perspective, Satan is not volitionally receptive to God at all, and therefore his pre-receptive evidence does not lead to the kind of salient transformative evidence arising from cooperation with God.

\section{MOTIVES FOR INTELLECTUALISM}

Proponents of intellectualism have various motives for their position, three of which merit attention here. First, they often seek aid from considerations about a needed method. In particular, they adopt a method for belief formation and belief revision, and then wield it across the board. This strategy is not mistaken in principle, but it needs to be handled cautiously, in a manner that does not preclude reasonable acknowledgment of genuine features of reality. For instance, we should be suspicious of any method that precludes reasonable acknowledgment of either human agents or mid-sized physical objects, such as tables and human bodies. We might say, then, that an adequate method of belief formation will call for an adequate meta-method of belief formation: that is, an adequate method regarding (the identification of) an adequate method of belief formation. Inquirers must avoid, however, an endless regress of required methods, if only because we do not possess an infinite number of such methods in regress.

A key question arising from a meta-method about a proposed method for belief will be: what does this method set as parameters for (evidential) acceptability in a set of beliefs? More specifically, does the method allow for (potential) reasonable acknowledgment of an elusive God who aims to redeem humans non-coercively? Or, instead, does it 
preclude such acknowledgment from the start? In the latter case, we may face methodological bias of a sort that can hinder the reasonable pursuit of truth. Of course, one might try to establish that our barring acknowledgment of an elusive God is well-grounded in our available evidence. That task, however, sets a tall order indeed for advocates of the position in question, because our available evidence does not seem exclusive in the manner required. It seems more open-ended than suggested by the position at hand.

If God exists and is available to humans, a method for inquiring about God should fit with reasonable, evidence-based acknowledgment of the character and purposes of God, and not preclude such acknowledgment. Philosophers have sometimes adopted methods that settle the issue of God's existence in advance of due attention to the relevant evidence. For instance, a method that requires an evidential basis in mundane sensory evidence will represent a highly questionable bias. The same is true of a method that requires conformity either to a materialist ontology or to the kind of experimental procedures typical of a chemistry laboratory. In general, then, we should not let a questionable method blind us from acknowledging genuine aspects of reality and the corresponding evidence. Instead, we should allow human experience of reality to play a key role in adjudicating among the many methods in circulation. Otherwise, we may have the proverbial oddity of putting the cart before the horse, or, at least, we may have an implausible bias in our method. More to the point, we should not allow a method to preclude volitionally sensitive evidence of God from the start.

The second motive for some commitments to intellectualism comes from an unduly restrictive demand for evidence of God. As suggested, Bertrand Russell (1970) anticipated his response if God were to meet him, perhaps after death: 'God, you gave us insufficient evidence.' Russell might have considered a bit more modesty in the presence of God, perhaps by inquiring about available evidence of God that is volitionally sensitive in its being acquired by humans. In that case, Russell might have asked: 'God, what purposes of yours led to your being subtle and elusive regarding the available evidence of your reality? Is such evidence volitionally sensitive in our acquiring it? If so, might this have a redemptive purpose?' It is disappointing that Russell gives no indication of being aware of such plausible questions for a God who is redemptive toward humans. He should have asked about the moral character and purposes of a God worthy of worship, in order to avoid begging key questions 
about the evidence for God. In that case, however, Russell would have had a big challenge on his hands, or at least on his will, because he, rather than God, would be subject to challenge on volitional grounds.

The lesson is that intellectualism, advocating mere intellectual reflection to settle the question of God's existence, is existentially too thin for the kind of evidence suitable to a redemptive God. Humans in need of redemption should not expect to know a redemptive God on the cheap, as if no volitional challenge is needed. Just as there is no place for cheap grace in a robust theology, so also there is no place for redemptively cheap evidence of a gracious God who seeks the redemption of humans. Many proponents of the arguments of natural theology run afoul of this lesson. These theorists assume that if atheists and agnostic just thought hard enough on our common evidence, they would come to acknowledge the reality of God. These atheists and agnostics, they assume, then would see the crucial role in reality for a First Cause, a Designer, or a Perfect Being, which (at least according to Aquinas, the godfather of modern natural theology) we all know to be God. The needed evidence for God, according to this position, is in our midst and even in our possession, but we need to think more rigorously to see its bearing on theism. That position, however, is too shallow, volitionally and existentially.

A serious problem is that the god of traditional natural theology (and its corresponding evidence) is not elusive in the manner to be expected of a redemptive God who bobs and weaves, and even hides, to challenge humans for their own redemptive good. This kind of redemptive God would not be the static solution to merely intellectual questions, but instead would seek to move humans, non-coercively, toward God at the level of their wills, to put God's will first in all things. That is, this God would aim to redeem humans as agents, and not just as thinkers. Like intellectualism, traditional natural theology neglects this key lesson, and therefore is defective. (For elaboration, see Moser 2010, chap. 3; 2012b; 2013, chap. 3.)

We can put the problem at hand in terms of divine presence as divine self-manifestation to humans. If God self-authenticates divine reality for humans by the self-manifestation of God's moral character (including agap $\bar{e}$ ), but seeks not to coerce humans to receive this manifestation, then God's self-manifestation is rejectable by humans. That is, the selfmanifestation of God's moral character to humans does not force the will of humans in a way that undermines their genuine agency in responding to God. As a result, God's self-manifestation allows humans to say no to it 
by excluding it from their focus. In other words, God is willing to withdraw divine self-manifestation to leave room for genuine human agency regarding divine presence. Such basic evidence of God's reality, then, is not static across human experience. It can vary relative to the volitional stance of its potential recipients, so as not to trivialize or to obscure the redemptive intent of divine intervention in human experience. (A notion of divine self-authentication, not to be confused with self-authentication of religious experience or of scripture, can be found in Mackintosh 1912 and Stewart 1940; see also Moser 2013, chaps. 3, 5.)

The third motive is not an avowed reason for intellectualism, but it still plays a psychological role in some commitments to intellectualism. The unexpressed motive, I propose, is desired avoidance of a volitional struggle with a redemptive God. Such avoidance has a range of detrimental results, including a coupling of intellectualism with a destructive kind of intellectual pride. This pride manifests itself in the common attitude that opponents of intellectualism, of a theistic or an atheistic variation, are intellectually dim in a peculiar manner. Such an attitude emerges even from many proponents of natural theology when their favoured evidence fails to convince critics. (We need not name names here.) This paper offers an alternative to such misplaced pride by shifting attention to volitional sensitivity in humans, beyond their intellectual skills. In doing so, it acknowledges the significance of the kind of volitional attitude candidly expressed by Thomas Nagel: 'I want atheism to be true ... I hope there is no God! I don't want there to be a God; I don't want the universe to be like that.' (1997: 130) Nagel worries that the existence of God would pose a serious 'cosmic authority problem' for us. The obstacle for Nagel, among many others, is clearly volitional, and not (just or even primarily) intellectual. Even so, Nagel is right: the existence of a perfectly loving, redemptive God would raise a cosmic authority problem for us humans, because God's perfect will would challenge our imperfect wills.

\section{CONCLUDING EXPECTATIONS}

In sum, intellectualism regarding the question of God's existence is a dead end relative to a truly redemptive God. It neglects the important consideration that a redemptive God would offer available evidence that is volitionally sensitive in its being possessed by humans. Whether atheist or theist, proponents of intellectualism have ignored this consideration to their own detriment. This lesson does not undermine the value of 
thinking in human faith in God. Instead, it puts such thinking in a proper context, with proper, redemptive bounds. This context allows God to seek to engage agents not just with their minds but also with their wills, for the sake of a human volitional commitment to the priority of God's will. As a result, inquirers should not uncritically expect God or enduring evidence for God's existence to be accessible just by human thinking about the evidence we possess.

God would seek to engage humans redemptively as agents, not just thinkers, and we should expect evidence of God to be elusive, variable, and challenging to that end. In particular, we should expect salient evidence of God to come through a Gethsemane crisis rather than mere casual reflection on our evidence. As a result, we should doubt any suggestion, such as that of Dawkins (2006: 52, 59), that evidence for God's existence is to be treated just like evidence for a scientific hypothesis. As an elusive personal agent, God would differ in significant ways from typical scientific objects, and this would yield a relevant difference in the two kinds of evidence.

Human inquiry about God, in the perspective offered here, is inextricably bound up with who a human intends and resolves to be, either in cooperation with God or in opposition to God (the latter including indifference toward God). In addition, the salient evidence for God comes not from abstract philosophical arguments, but instead from God's self-manifestation to humans at God's opportune times. This selfmanifestation can come in human conscience, but it cannot come just by human resources. We lack the power to manifest God's moral character on our own, and therefore we must be prepared to receive evidence for God as a redemptive gift rather than as our earning or creation.

The redemptive gift would include the power of righteous love experienced typically in human conscience, and this power (as representing the moral character of God) is to be received and obeyed. Given its immediacy, humans have no need to argue to it by natural theology. This power amounts to divine self-authentication via the self-manifestation of God's moral character to humans. Inquiry about God looks very different from this perspective, especially very different from the troubled position of intellectualism. It takes on an existential value that intellectualism omits. In particular, it suggests that inquirers of God may very well be under inquiry themselves, by a redemptive God. Each inquirer must settle firsthand whether this is actually so, specifically for his or her own will relative to a morally perfect will. In 
this regard, the vital challenge of Gethsemane bears on all human agents, sooner or later. A theology accompanied by such an epistemology will be not only resilient in the face of familiar objections to theism but also existentially vital for cooperative humans. The outstanding question is, finally, whether we humans are sincerely willing to cooperate with God's perfect will.

\section{BIBLIOGRAPHY}

Dawkins, Richard. 2006. The God Delusion (New York: Houghton Mifflin) Farmer, Herbert H. 1943. Towards Belief in God (New York: Macmillan)

Ferré, Nels. 1961. 'The Nature and Power of Christian Experience', in Ferré, Searchlights on Contemporary Theology (New York: Harper), pp. 184-95

Forsyth, P.T. 1909. The Person and Place of Jesus Christ (London: Independent Press)

Furnish, Victor Paul. 1972. The Love Command in the New Testament (Nashville: Abingdon Press)

Mackintosh, H.R. 1912. The Doctrine of the Person of Jesus Christ (New York: Charles Scribner's Sons)

Minear, Paul S. 1966. Eyes of Faith, 2nd ed. (St. Louis: Abbott Books)

Moser, Paul K. 1989. Knowledge and Evidence (Cambridge: Cambridge University Press)

Moser, Paul K. 2008. The Elusive God (Cambridge: Cambridge University Press) Moser, Paul K. 2010. The Evidence for God (Cambridge: Cambridge University Press)

Moser, Paul K. 2012a. 'Undermining the Case for Evidential Atheism', Religious Studies, 48 (1): 83-93

Moser, Paul K. 2012b. 'Natural Theology and the Evidence for God', Philosophia Christi, 14 (2): 305-11

Moser, Paul K. 2013. The Severity of God (Cambridge: Cambridge University Press)

Nagel, Thomas. 1997. The Last Word (New York: Oxford University Press)

Ramsey, Paul. 1943. 'The Great Commandment', Christianity and Society, 8: 29-35

Russell, Bertrand. 1970. 'The Talk of the Town', The New Yorker (February 21, 1970), p. 29. Cited in Al Seckel, ed., Bertrand Russell on God and Religion (Buffalo: Prometheus, 1986), p. 11

Shope, Robert K. 2002. 'Conditions and Analyses of Knowing', in Paul Moser, ed., The Oxford Handbook of Epistemology (New York: Oxford University Press), pp. 25-70

Stewart, James S. 1940. 'Who is this Jesus?', in Stewart, The Strong Name (Edinburgh: T\&T Clark), pp. 80-89

Terrien, Samuel. 1978. The Elusive Presence (New York: Harper \& Row) 